\title{
Role of Pro-Thrombolites in the Geomorphology of a Coastal Lagoon ${ }^{1}$
}

\author{
D. A. Siqueiros-Beltrones ${ }^{2}$
}

\begin{abstract}
Thrombolites are lithified biosedimentary structures generated by entrapment, precipitation, and binding of sediments promoted by growth and metabolic activity of cyanobacteria. Beaches of the coastal lagoon known as Ensenada de La Paz in Baja California Sur, México, are bordered by sedimentary formations of cyanobacterial origin identified as pro-thrombolites (incipient thrombolites) that represent a first record for the region and México. Observed thrombolithic structures show grains of varied sizes embedded within a fine-grain micritic matrix, which may be surrounded by medium-grain cementing micrite. Different degrees of consolidation occur-some crumble easily, whereas others require some manual force to break. These pro-thrombolites consist of platforms $>20 \mathrm{~cm}$ thick and/or fragments of assorted sizes and forms. In some cases the structures have lithified, forming rocky plates (thrombolites). The extension and wide distribution of pro-thrombolites around the $\mathrm{La} \mathrm{Paz} \mathrm{la-}$ goon suggests that these structures could have determined its evolution from an original (primitive) cove into a lagoon. That is, the formation of prothrombolites through the entrapment and binding of sediments may have eventually altered water circulation, promoting sand sedimentation causing the formation of the El Mogote sand bar. Likewise, pro-thrombolites may have formed large extensions of headlands through accretion. Thus, several square kilometers of populated land around the La Paz lagoon may have thrombolithic origin.
\end{abstract}

Microbial structures seem to be a common feature along the coasts of the Baja California Peninsula. Ephemeral microbial mats have been seen to form in some places where conditions change abruptly (SiqueirosBeltrones 1988, 1990). However, a large part of the beaches of the Ensenada de La Paz (Baja California Sur, México) coastal lagoon are covered by permanent microbial mats and bordered by biosedimentary structures

${ }^{1}$ This study was supported by grants from Instituto Politécnico Nacional through projects CGPI-20040024 and 20050069. The author is a Comisión de Cooperación y Fomento de Actividades Académicas and Estímulos al Desempeño de los Investigadores fellow (Instituto Politécnico Nacional). Manuscript accepted 26 June 2007.

${ }^{2}$ Departamento Plancton y Ecología Marina, Centro Interdisciplinario de Ciencias Marinas (CICIMAR), Instituto Politécnico Nacional, P.O. Box 592, La Paz, B.C.S., México, 23000 (e-mail: dsiquei@ipn.mx).

Pacific Science (2008), vol. 62, no. 2:257-269

(C) 2008 by University of Hawai'i Press

All rights reserved generated or promoted by the growth of filamentous cyanobacteria. These structures were tentatively identified as living or incipient thrombolites during a sampling for benthic diatoms in assorted substrata (Siqueiros-Beltrones 2006). Thrombolites are biosedimentary structures generated by the entrapment, binding, and consolidation of sediments as a result of the metabolic activity and growth of microorganisms, particularly cyanobacteria. Contrary to the structure of stromatolites, in thrombolites no lamination is observed (Charpy et al. 1999, Riding 2000, Shapiro 2000, Stal 2000). At least five types of thrombolites may be recognized, all characterized by their clotted structure (Riding 2000).

In this study the term "pro-thrombolite" is preferred over "living thrombolites" for the structures found in the $\mathrm{La} \mathrm{Paz}$ lagoon that show no lithification. These, unlike the conspicuous microbial mats associated with them, have accreted by trapping sediments, forming a clotted, semiconsolidated biosedimentary structure. 

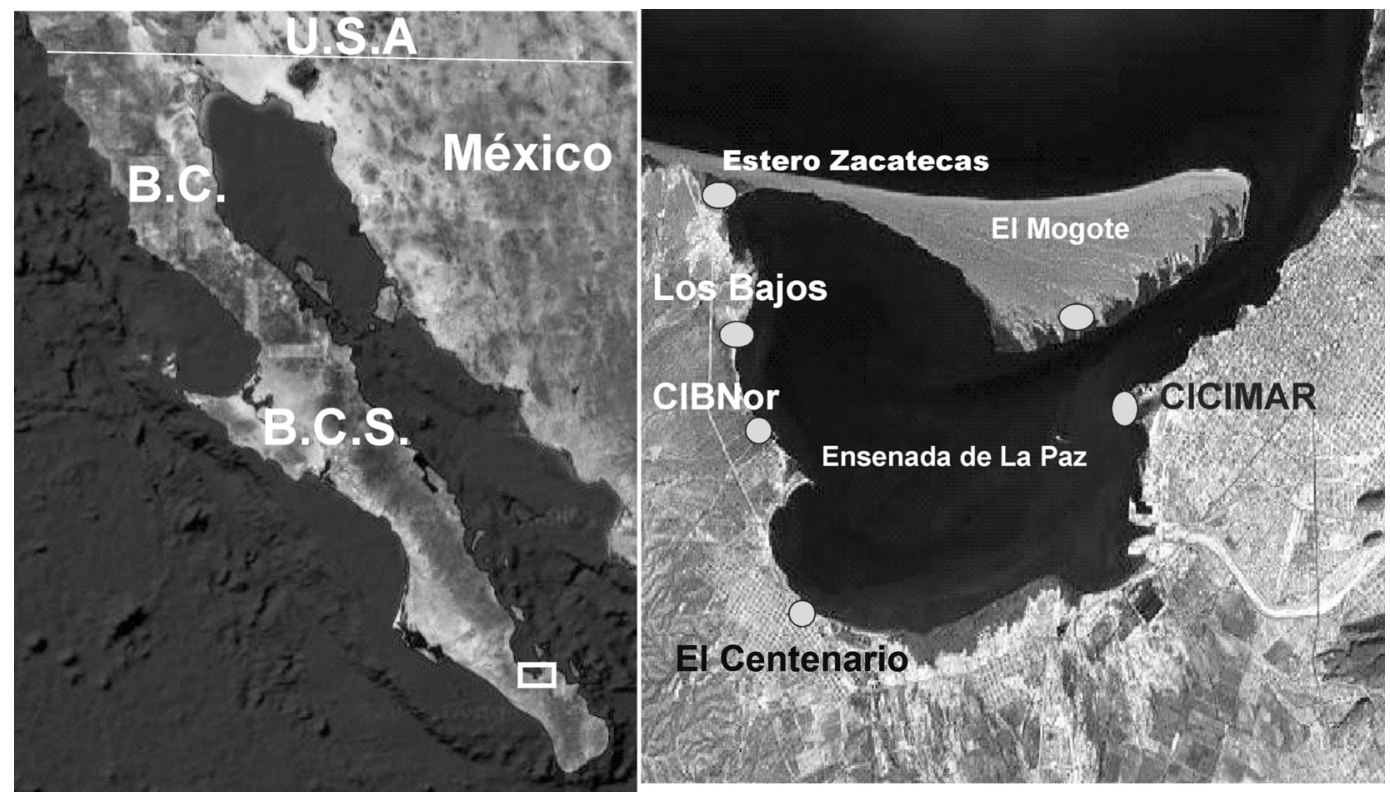

Figure 1. Location of sites where pro-thrombolites were first surveyed in the Baja California Peninsula, and sites where lithified thrombolites were found (Estero Zacatecas, El Conchalito [to the east of CICIMAR], and El Mogote).

Fossil thrombolites have been observed farther north in the Baja California Peninsula in the area of Bahía Concepción (MirandaAviléz et al. 2005), where living hot-spring (laminated) stromatolites are also found (Canet et al. 2005). However, prothrombolites have not been hitherto reported in any Mexican marine environment. Although pro-thrombolites were apparently noted at El Centenario in the Ensenada de La Paz (Figure 1) by Cruz-Orozco et al. (1989), they were recorded as beach rock. Beach rock formation has been related to stromatolites, and these require environmental conditions similar to those thrombolites need to develop (Charpy et al. 1999). In fact, some controversy exists over whether the origin of beach rock is biotic (cyanobacteria) or abiotic, though both factors seem to contribute (Krumbein 1979). In a recent review of the geology of the La Paz lagoon no other account of beach rock is mentioned (AlvarezArellano et al. 1997).
Cyanobacterial structures distributed along the Baja California Peninsula have been studied to understand the processes by which stromatolites are formed (Horodysky and von der Haar 1975, Horodysky 1977, Margulis et al. 1980) and to provide clues of past microbial activity. But do these biosedimentary structures play other roles of ecological or geological importance? Many questions remain unanswered: What is the proportional taxonomic composition of cyanobacteria in various stages of the formation of thrombolithic structures? What is the growth rate of the said structures? How are sediments trapped and what determines their texture? How does lithification occur and what is the precise role of cyanobacterial mats in this process? How do these structures affect mangrove settlement and do they interact to promote progradation of the lagoon margins? How extensive are pro-thrombolithicgenerated grounds?

Here I address only the first question. My 
initial observations led to the assumption that pro-thrombolithic activity might have had an important role in the geomorphologic origin of the La Paz lagoon and headlands. This prompted the hypothesis that seaward prothrombolite accretion influenced the transformation of the primitive cove (the Ensenada de $\mathrm{La} \mathrm{Paz}$ ) into a lagoon by providing the necessary spit (Nava-Sánchez and CruzOrozco 1989) for the accumulation of sand. This eventually led to the formation of the El Mogote sand bar (Figure 1). Moreover, in other parts of the lagoon pro-thrombolithic growth may have directly generated large extensions of land through progradation. To support this hypothesis the following subordinate hypotheses were contrasted: (1) Because living thrombolites contribute to the progradation of the lagoon margins due to their seaward growth, active pro-thrombolites (exposed even at high tide) should occur over much of the lagoon margins; (2) Thrombolithic structures are to be found extending landward, either buried or exposed; (3) Lithified thrombolithic structures (thrombolites) should be found landward (perhaps as beach rock) behind the mangrove fringe; (4) Consolidated thrombolithic structures, including lithified forms, should be present at the base of El Mogote and at the base of other seaward land projections inside the lagoon.

\section{Study Area}

The Ensenada de La Paz coastal lagoon is located within Bahía de La Paz, between $20^{\circ}$ $06^{\prime}$ and $24^{\circ} 11^{\prime} \mathrm{N}$ and $110^{\circ} 18^{\prime}$ and $110^{\circ} 26^{\prime}$ $\mathrm{W}$, and separated from it by the El Mogote sand bar (Figure 1). The tidal regime is semidiurnal and the flow from high to low tide is more intense, causing strong currents that keep the lagoon from filling up by sediment accumulation. Salinities vary between 34 and $36 \mathrm{ppt}$, depending on the season (JiménezIllescas et al. 1997). Based on temperature variation, three periods may be distinguished: (1) March-June, (2) July-October, and (3) November-February; the last two are considered rainy seasons (Salinas et al. 1990). At the mouth of the lagoon, mean temperatures of $23.5^{\circ} \mathrm{C}$ in April-June and $30.25^{\circ} \mathrm{C}$ in JulySeptember have been recorded (CervantesDuarte et al. 2001).

\section{MATERIALS AND METHODS}

Initially, samplings were made at four localities inside Ensenada de La Paz: (1) El Conchalito, on the campus of Centro de Interdisciplinario de Ciencias Marinas (CICIMAR)-Instituto Politécnico Nacional $\left(24^{\circ} 08^{\prime} 29^{\prime \prime} \mathrm{N}\right.$ and $\left.110^{\circ} 21^{\prime} 07^{\prime \prime} \mathrm{W}\right)$; (2) the beach of El Centenario $\left(24^{\circ} 06^{\prime} 38^{\prime \prime} \mathrm{N}\right.$ and $110^{\circ} 25^{\prime} 04^{\prime \prime} \mathrm{W}$ ); (3) northwest of the Centro de Investigaciones Biológicas del Noroeste (CIBNor) $\left(24^{\circ} 08^{\prime} 35^{\prime \prime} \mathrm{N}\right.$ and $110^{\circ} 25^{\prime} 47^{\prime \prime}$ $W$ ); and (4) Los Bajos (24 $09^{\prime} 01^{\prime \prime} \mathrm{N}$ and $110^{\circ} 25^{\prime} 49^{\prime \prime} \mathrm{W}$ ), named after the conspicuous mudflats during low tide (Figure 1). At all localities, fragments from thrombolithic formations were collected using a hammer and spatula. Approximate measurements were made of the thrombolithic beds. Salinity of water and sediments, and water temperature were measured.

To test the four hypotheses, further explorations were conducted: searching for buried thrombolithic structures behind the mangrove line (hypotheses 1 and 2) and looking for different degrees of consolidation of thrombolithic structures up to lithified forms (hypotheses 3 and 4). These were carried out mainly at the base of El Mogote and at El Conchalito (Figure 1), where thrombolithic structures were located visually (exposed plates) or by poking with a shovel along the mudflats at low tide. Later, a final exploration was conducted at a beach in El Mogote directly across from CICIMAR to check another report of beach rock, which was assumed to be thrombolithic in nature. Photographs were taken of the different types of formations.

In the laboratory, filamentous cyanobacteria were scraped off and separated using a dissecting needle for observation in fresh (squash) preparations. Identification followed the works by Charpy and Larkum (1999), López-Cortés (1999), and Whitton and Potts (2000). A part of each scraping was processed 


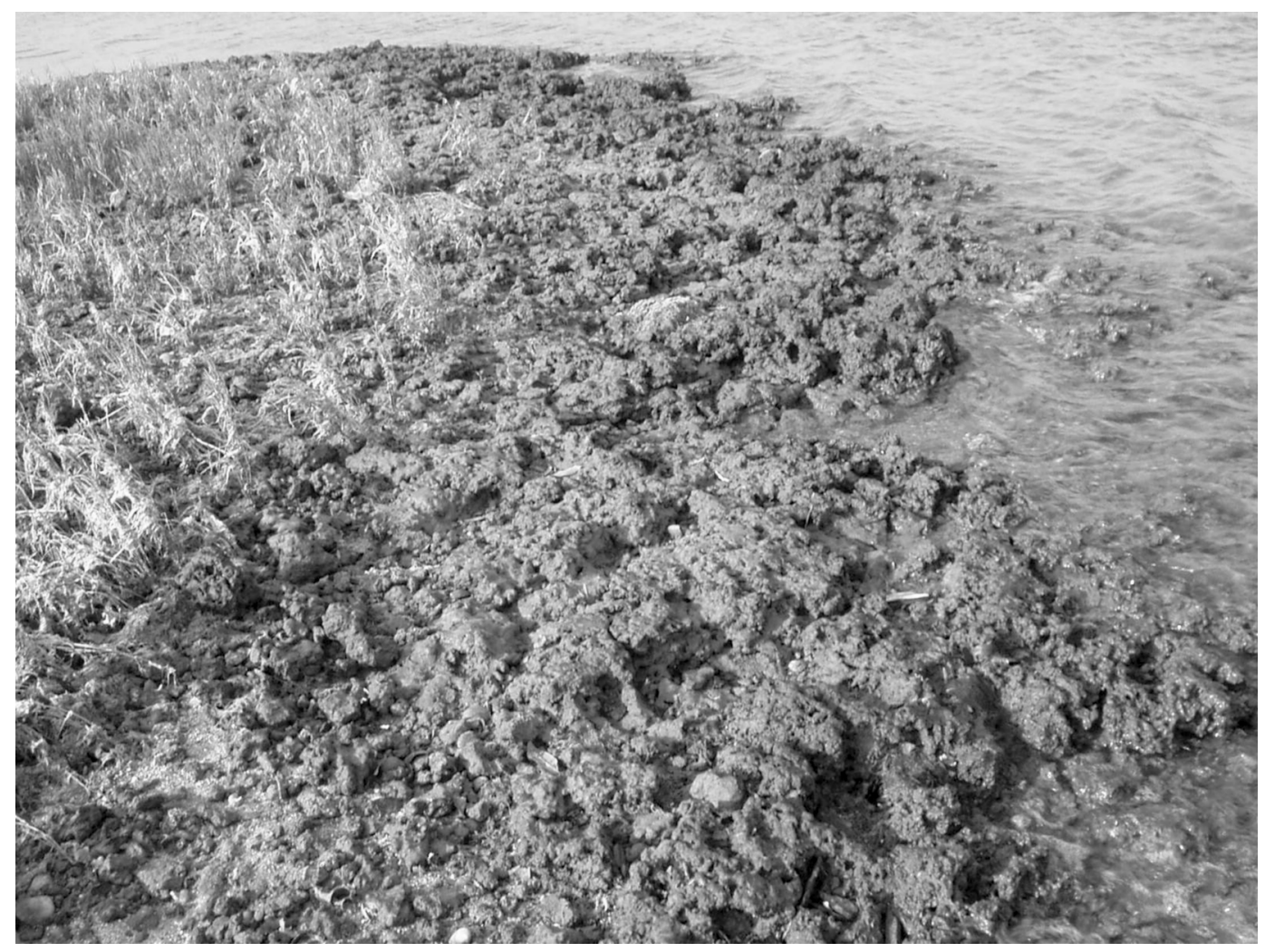

FIgURE 2. First thrombolithic formation observed, at El Conchalito (CICIMAR).

for the mounting of diatoms, which were investigated separately (Siqueiros-Beltrones 2006). The thrombolite fragments were examined to determine their degree of consolidation and to make thin sections in the geology laboratory.

\section{RESULTS}

\section{Description of Pro-Thrombolites}

The thrombolithic structures in Ensenada de La Paz lagoon consist of conglomerated or clotted sediments of different textures. The degree of consolidation varies from semiconsolidated (i.e., those that crumbled more or less easily [pro-thrombolites]) to hard lithified plates (thrombolites). Frequently, whole or fragments of clam shells were seen em- bedded in the pro-thrombolites, as well as fouling by balanoids. The overall area of the formations has not been estimated. They include extensive platforms and fragments of assorted sizes and forms that together amount to varied areas resembling sandstone or (fossil) muddy sandstone. The first recognized pro-thrombolite is located to the north of CICIMAR (Figure 2). The exposed spit covers approximately $85 \mathrm{~m}^{2}$ and is seasonally occupied by Salicornia sp. On other prothrombolithic formations in the vicinity, mangrove trees are anchored (Figure 3).

At El Centenario discontinuous prothrombolithic platforms of approximately 40 and $30 \mathrm{~m}^{2}$ can be observed. However, the CIBNor locality showed the best-defined platforms, consisting mainly of consolidated sediments with a discontinuous covering of 


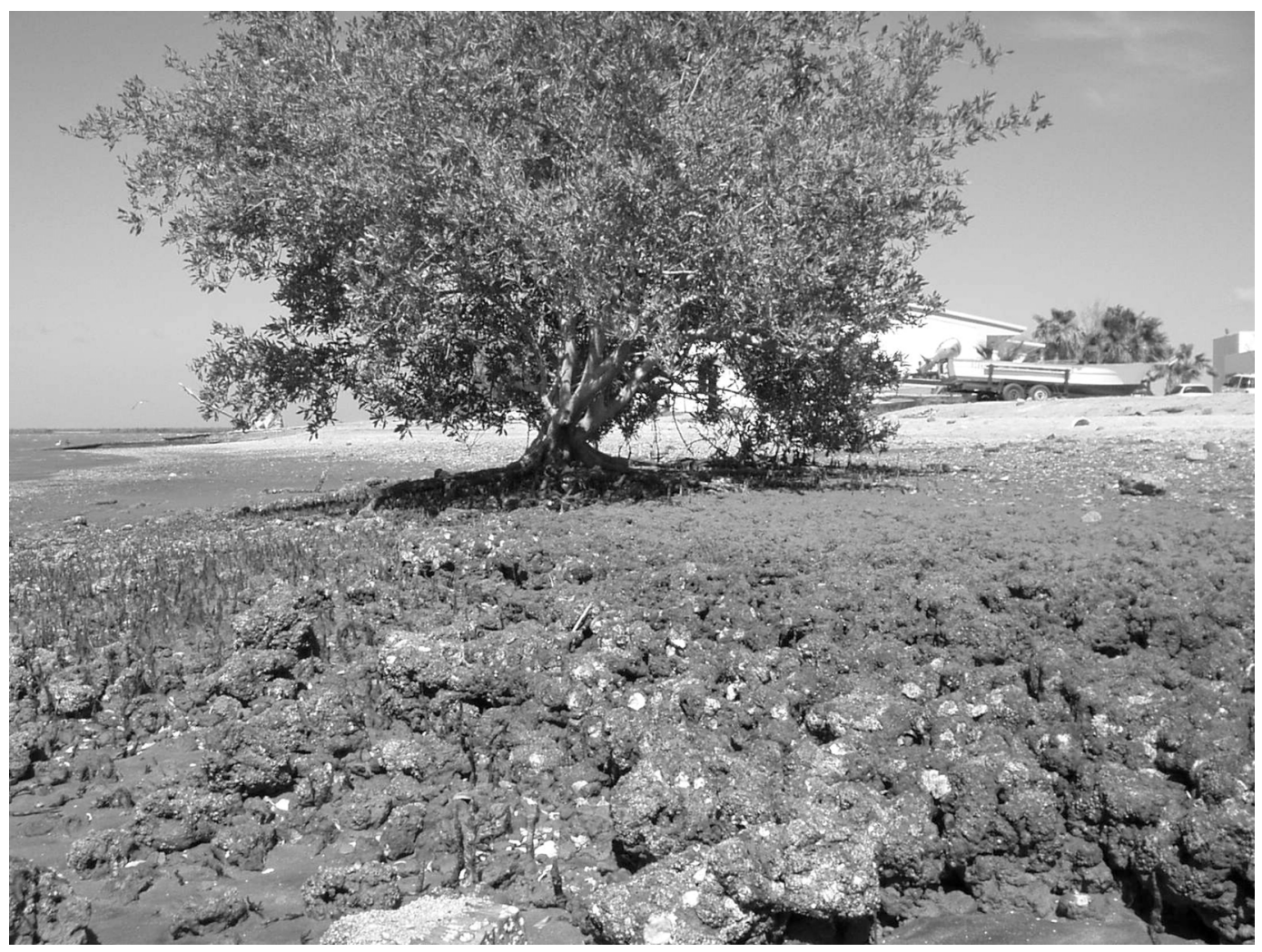

FIGURE 3. Pro-thrombolite bed showing an anchored mangrove (Avicennia germinans) at El Conchalito (CICIMAR).

cyanobacteria (Figure 4). The live portion extended almost $340 \mathrm{~m}^{2}$, but other platforms could be seen extending to the southeast of CIBNor. Finally, at Los Bajos prothrombolites extended about $60 \mathrm{~m}^{2}$, although other formations were distributed to the northwest.

Water temperature varied between 24 and $29^{\circ} \mathrm{C}$, and salinity from 35 to $40 \mathrm{ppt}$, which are in the previously reported ranges for the area. Sediments showed a maximum variation of 34 to 100 ppt at El Centenario in October.

\section{Associated Taxa}

Active pro-thrombolites are covered by a complex sheet of microalgae, principally cyanobacteria and diatoms. The main cyanobacteria taxa were Microcoleus chthonoplastes, whose long multiseriate filaments (Figure $5 a, b, c$ ) exhibit thick sheaths, and Oscillatoria limosal Lyngbya aestuarii (Figure $5 d$ ). Also common were thinner unidentified oscillatoriales that break down into hormogonia, plus Spirulina sp., Oscillatoria spp., Calothrix, and unicellular forms Chroococcus turgidus and Aphanotece sp.

Extensive cyanobacterial mats, closely associated with the pro-thrombolites, are seen distributed homogeneously all over the exposed mudflats in the lagoon during low tides and extending subtidally. Abundant snails (Cerithidia mazatlanica) may be seen grazing actively on and around the formations.

The diatom survey (Siqueiros-Beltrones 2006) yielded 150 taxa, mostly pennate raphid forms, although araphid and centric forms were frequent. Observation of fresh samples showed that diatoms were alive, indicating 


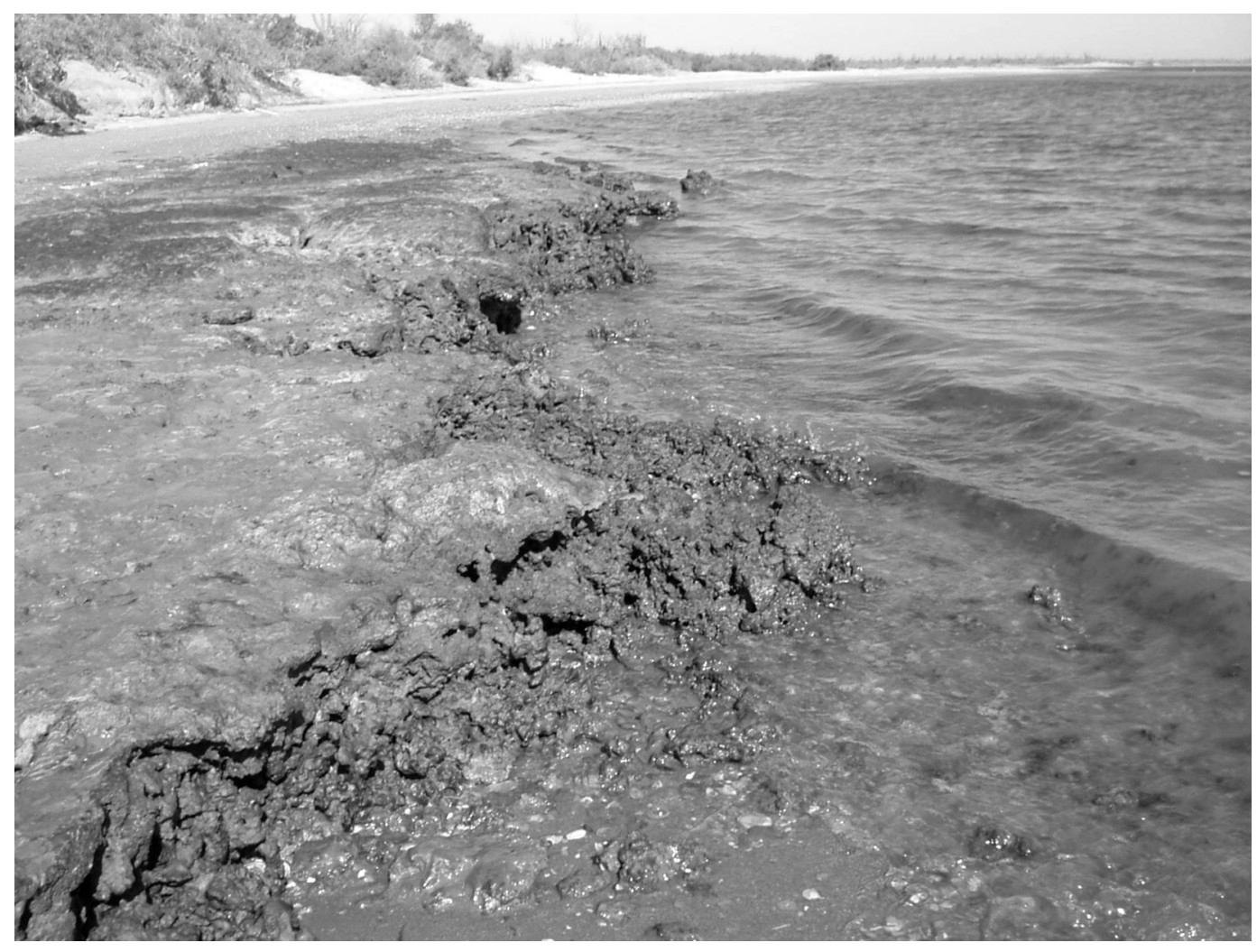

Figure 4. Extensive rocklike pro-thrombolithic platforms at CIBNor during low tide.

that an assemblage actually develops on the pro-thrombolites. The high species richness does not differ from that of other assemblages in the region, and many taxa indicate the influence of the local mangrove system (e.g., 10 species of Diploneis, six species of Lyrella, and eight species of Mastogloia), whereas several others are commonly associated with cyanobacterial mats (e.g., Gyrosigma scalproides var. eximium and Mastogloia pumila). However, their abundance was much lower than in the surrounding sediments. Moreover, dense mats of pennate diatoms were observed surrounding pro-thrombolites (Los Bajos), with a different species composition.

During a second exploration, other prothrombolites were observed to the east of CICIMAR and were common up to the base of El Conchalito Peninsula (Figure 6), where supralitoral formations occurred. Furthermore, buried compact structures $>20 \mathrm{~cm}$ thick were located by digging at the eastern CICIMAR campus limits. Together these constitute evidence of extensive ground formation. Furthermore, at El Comitán (the beach where CIBNor is located) and El Centenario pro-thrombolithic structures are common in the upper intertidal, and in both localities large areas of ground appear to have been generated (Figure 7a,b). In the latter, extensive cyanobacterial mats can be observed in the exposed intertidal showing raised surfaces due to the accumulation underneath of very fine sediments. These were interpreted as representing incipient prothrombolites (Figure 8a,b).

In the area known as Estero Zacatecas, where El Mogote forms an angle with the 


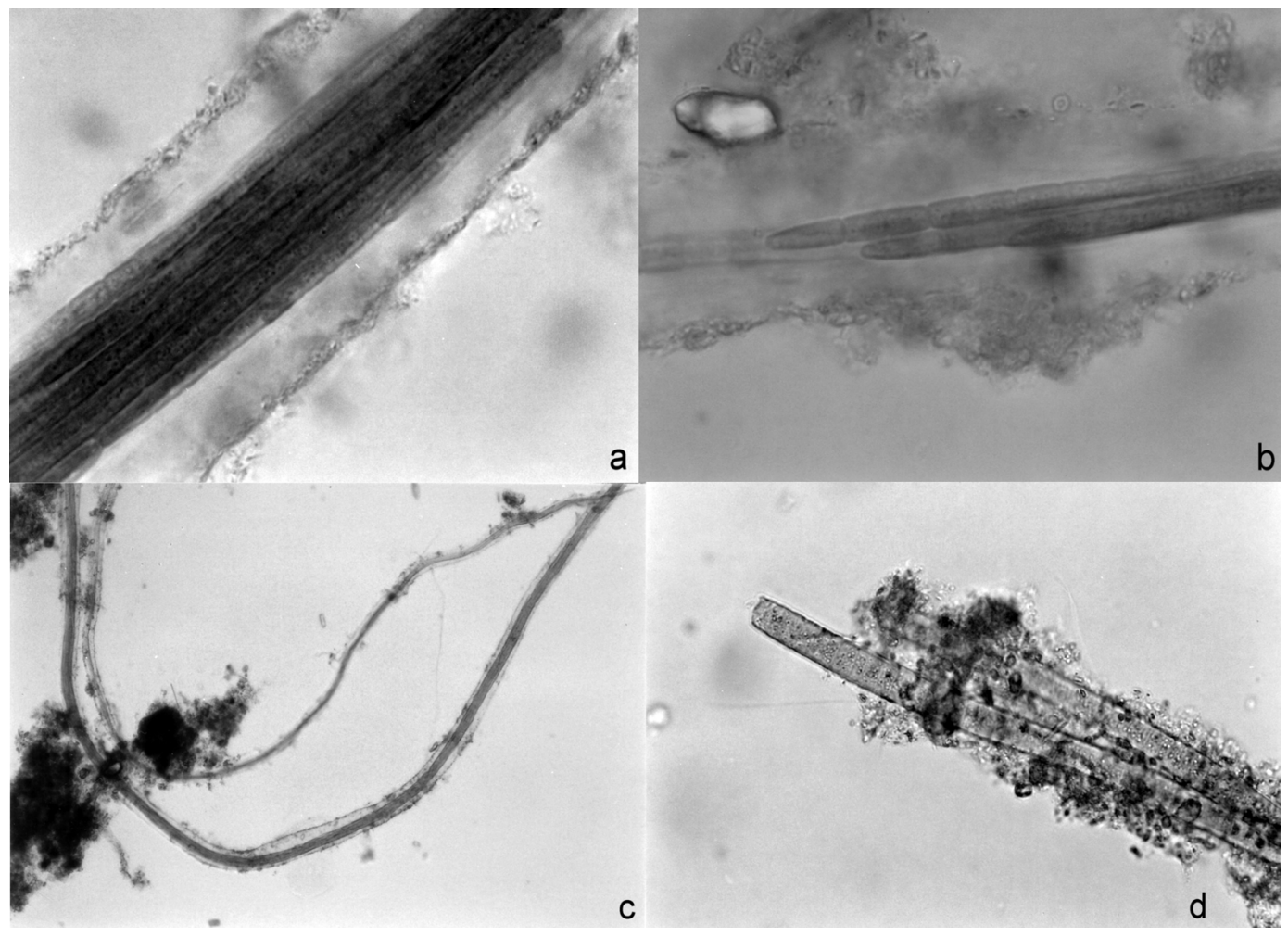

FigURE 5. Microcoleus chtonoplastes: $a$, Multiseriate filament with thick mucilaginous sheath $(1,000 \times)$; $b$, apex of trichomes inside the sheath $(1,000 \times) ;$, filament at $200 \times$. Oscillatoria limosa/Lyngbya aestuarii, $d$.

coastline (Figure 1), pro-thrombolites were common either as isolated structures (Figure 9) or extending behind the mangrove fringe and serving as substrate for Salicornia sp. plants.

\section{Thrombolites}

On higher mudflats of Estero Zacatecas, lithified plates (thrombolites sensu stricto) were discovered (Figure 10). This agrees with the hypothesis that both prothrombolites and thrombolites (lithified plates) would be found at the base of the El Mogote sand bar. Thus, under the assumption that this should also hold for other points that project seaward such as El Comitán and El Conchalito, I explored landward behind the mangroves at both localities. There I found structures showing different degrees of consolidation (from hand breakable to stonelike), including fragmented plates. The lithified plates were smaller than the ones from Estero Zacatecas and varied from 1 to $2 \mathrm{~cm}$ thick with compacted sediments adhered underneath.

The first series of petrographic analyses of thrombolites showed that lithification of clotted sediments is accomplished through cementation by micrite. Microscopic examination of thin sections under $10 \times$ magnification showed grains of various sizes including quartz, feldspar, olivine, phosphorite, oolites, shell fragments, and amphibolites. Most grains were rounded, but subrounded and angular grains were also common. These characteristics and grain size varied in samples from different sites. Grains were embedded 


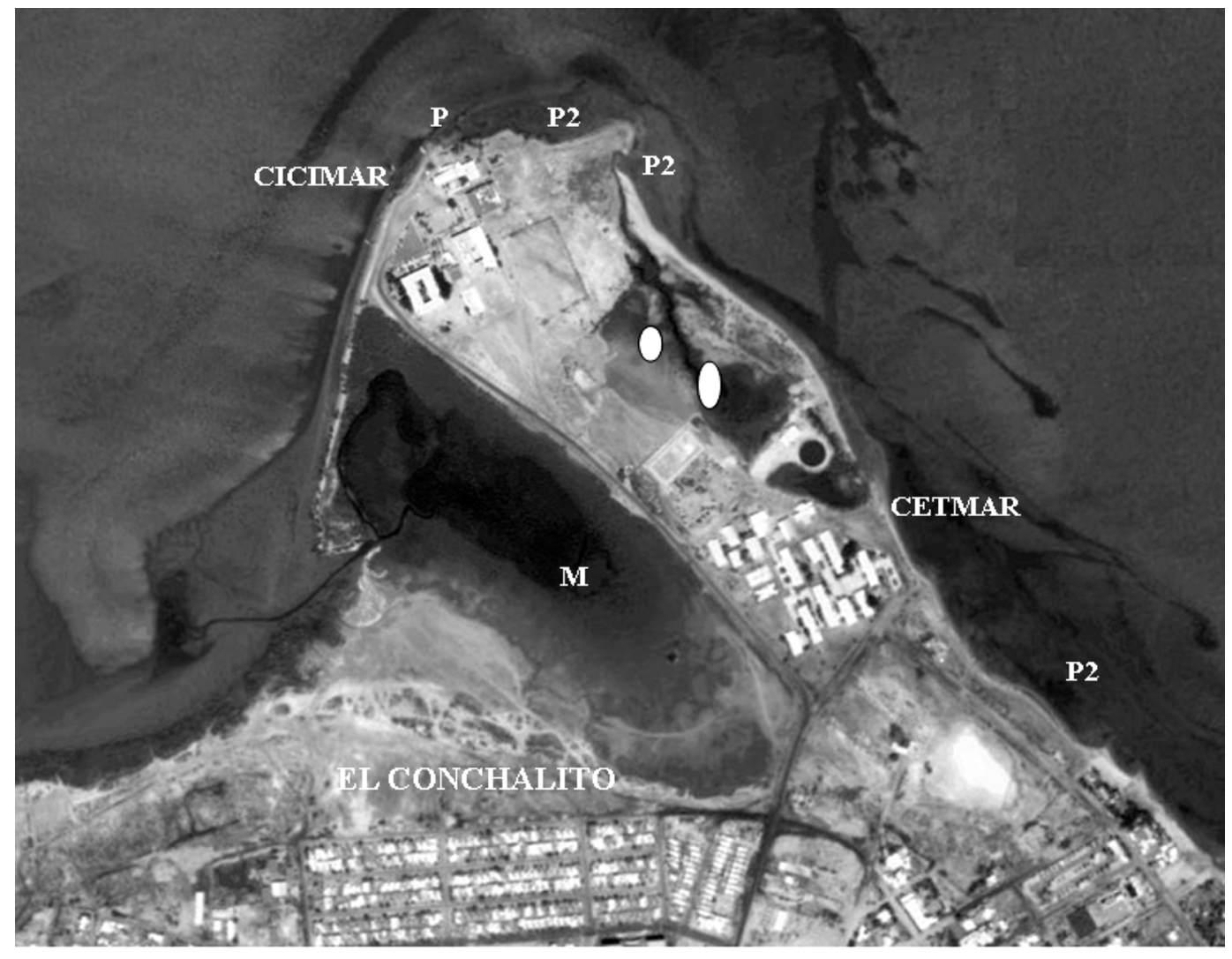

Figure 6. View of El Conchalito Peninsula and original sampling site (P), new sites with pro-thrombolites (P2), and thick semiconsolidated (larger white oval) and lithified plates (smaller white oval). Mangrove swamp, M. Modified from Google Earth (Europa Technologies 2007).
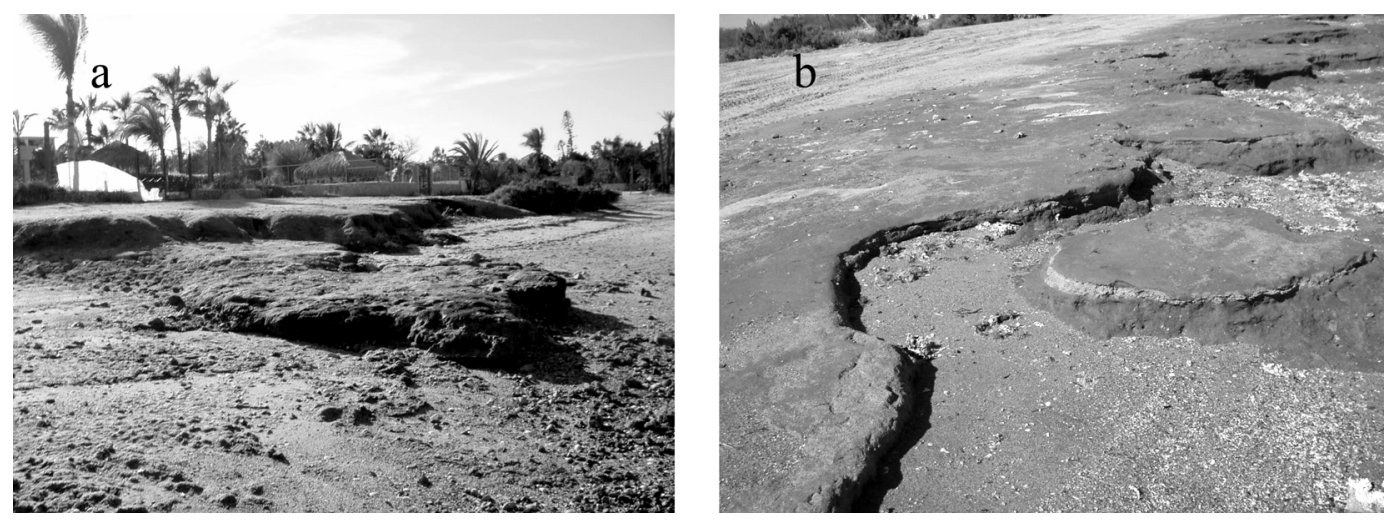

FIGURE 7. Intertidal pro-thrombolithic formations in (a) El Centenario and (b) El Comitán showing erosion by wave action. 

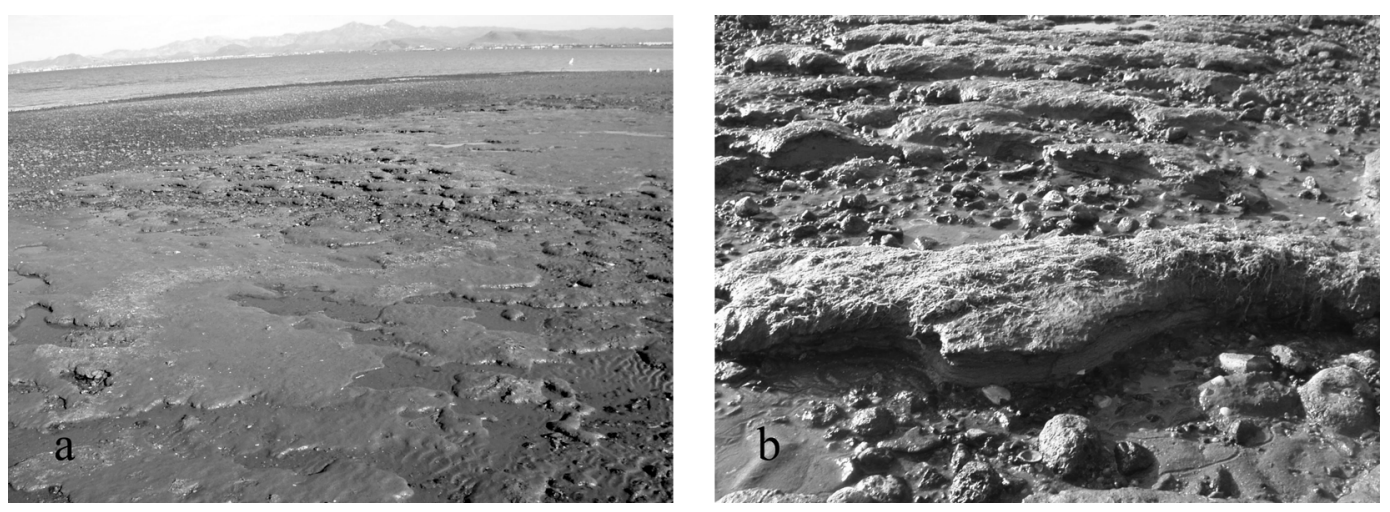

FIgURE 8. Panoramic (a) and close-up (b) views of accreting cyanobacterial mats that may represent incipient prothrombolites at El Centenario, Ensenada de La Paz lagoon, B.C.S.

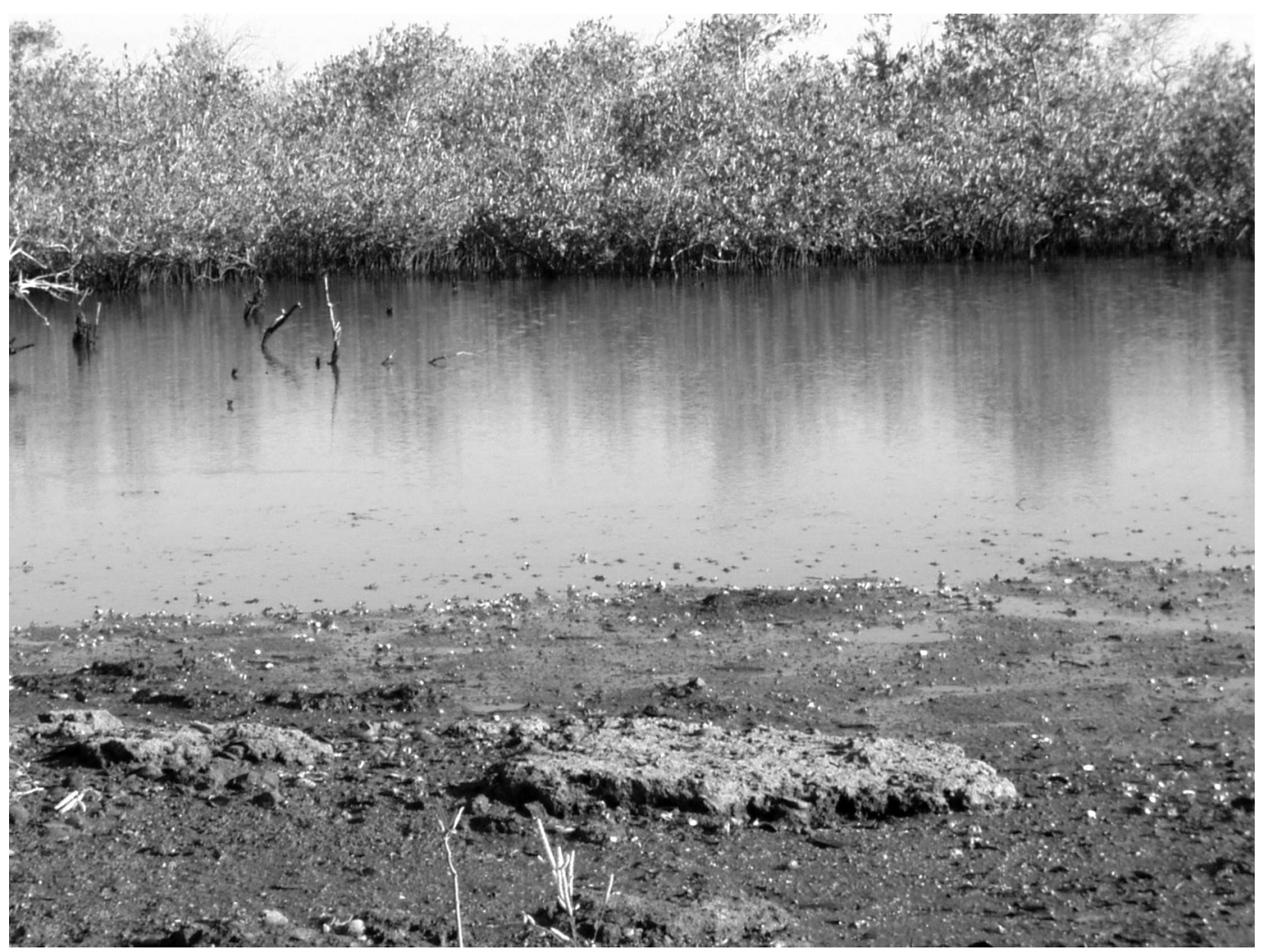

FIGURE 9. Exposed pro-thrombolite behind the mangrove line at Estero Zacatecas. 


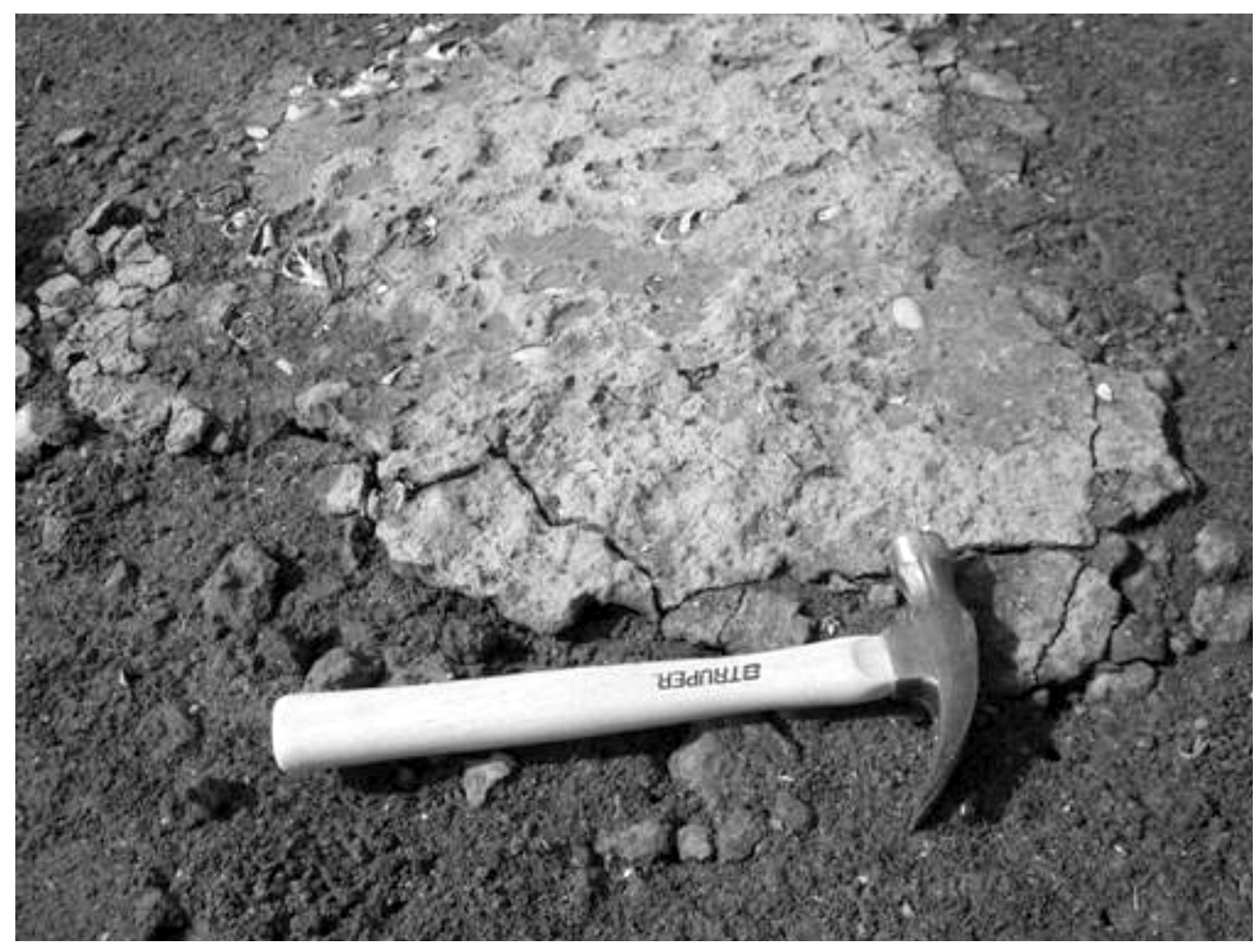

Figure 10. One of many thrombolithic plates found in Estero Zacatecas mudflats.

within a fine-grain micritic (microcrystalline calcite) matrix and were sometimes surrounded by medium-grain cementing micrite, which was also observed filling pores. Porosity varied from 10 to $40 \%$. No lamination existed in these structures, and no traces of cyanobacteria or diatoms were detected.

At an El Mogote beach across the channel north of CICIMAR, pro-thrombolites serve as anchoring points for mangrove trees. In one site, various stages of thrombolithic formations are present, including cyanobacterial mats, pro-thrombolites with various degrees of consolidation, and thick, lithified thrombolithic plates just above the intertidal level. Thick thrombolites found nearby show more complex development (Figure 11), and others exhibit what appear to be rhizoliths projecting from beneath the lithified plates.

\section{DISCUSSION}

The term "thrombolite" is derived from the fact that trapped sediments have been conglomerated and consolidated by cyanobacteria and become lithified without a laminated structure. In many cases, after the trapping and consolidation of the sediments has occurred, they remain active and growing, hence defining the pro-thrombolite stage. Eventually they may become inactive, although without reaching lithification, thus forming sedimentary (pro-thrombolithic) platforms, as in El Centenario and El Comitán.

The thrombolites found in Ensenada de La Paz lagoon are different from the ones in Australian hypersaline lakes but resemble live stromatolites from the Bahamas and Australia (Whitton and Potts 2000). Closer compari- 


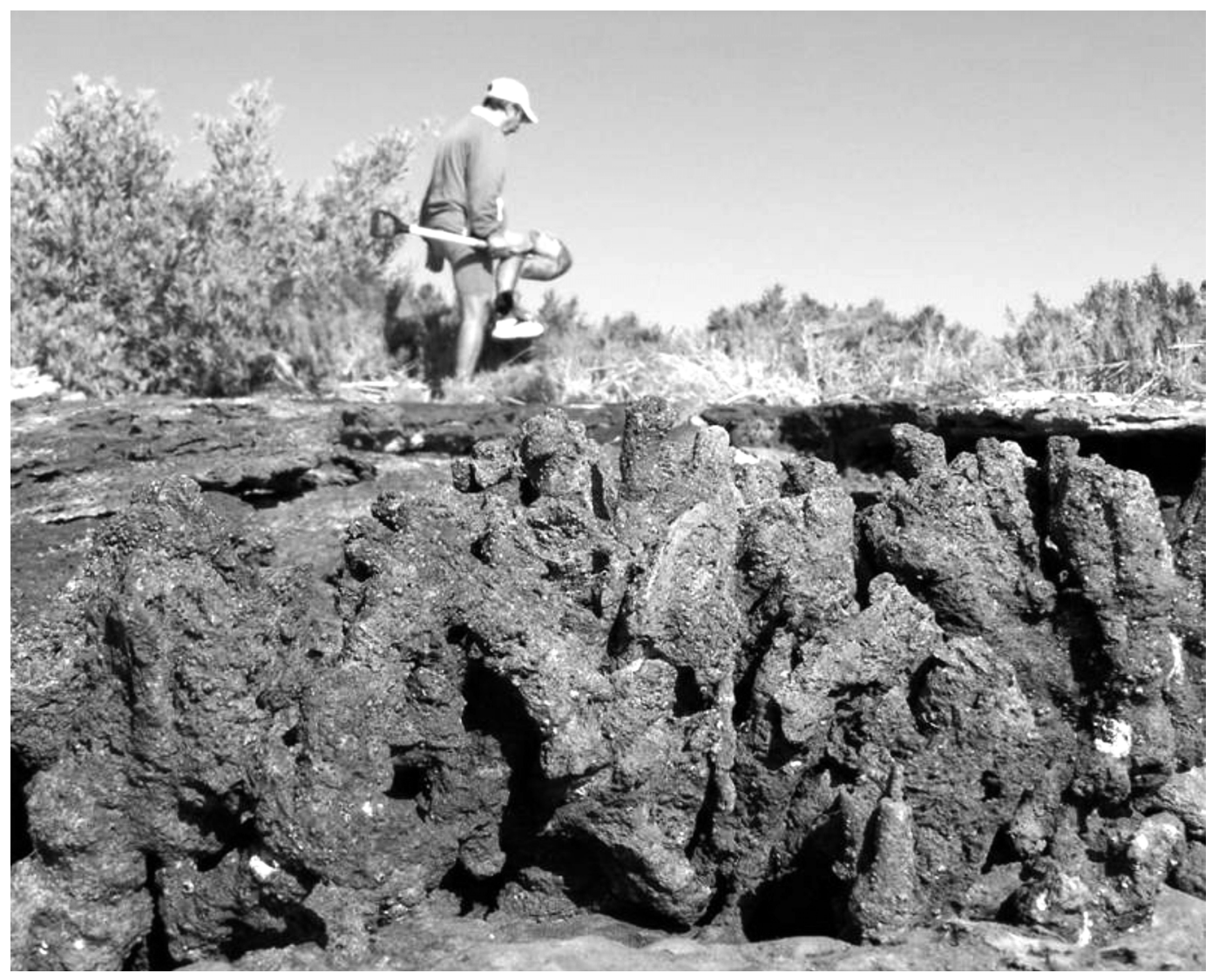

FIGURE 11. Thick thrombolithic formations at an El Mogote beach showing complex growth form.

son is needed to determine whether all of these pertain to the same type of thrombolithic structures (Riding 2000) or if a different type forms in the Ensenada de La Paz lagoon under certain conditions.

Most information on thrombolites derives from the study of fossil deposits. Thrombolites became conspicuous in the ProterozoicCambrian boundary (Riding 2000). In Bahía Concepción, B.C.S., fossil deposits include rhodolith beds, muddy sandstone, rhizoliths, and mangroves (Johnson and LedesmaVásquez 1997) as well as stromatolites and thrombolites (Miranda-Aviléz et al. 2005). Recent and fossil stromatolites are also associated with the presence of hot springs (Canet et al. 2005).

The formations described in Ensenada de
La Paz represent a first record of thrombolites from a nonfossil deposit for the region and México, which are quite recent, based on the estimated age of the lagoon $(5,000-6,000$ yr [Nava-Sánchez and Cruz-Orozco 1989]). Likewise, this is the first time that the identification of pro-thrombolites as active growing predecessors to thrombolites and their role in the geomorphology of coastal lagoons are addressed. In this perspective, environmental conditions that determine thrombolite formation are actually playing a larger role in the transformation of ecosystems.

Shoaling conditions, frequent exposure, and low dynamics in the lagoon seem to be playing an important part in the formation of thrombolithic structures. These, together with high concentrations of carbonates re- 
quired for their formation (Riding 2000), enhance the thrombolithic processes in the Ensenada de La Paz lagoon. Thus, although environmental conditions necessary for the formation of thrombolites are often considered extreme (Charpy et al. 1999), in the Ensenada de La Paz this does not seem to be the case because water temperature and salinity variation occurs within the reported ranges for the area. Although sediments may reach extreme salinities $(100 \mathrm{ppt})$, the density and species richness of pennate diatoms observed in the sediments surrounding the prothrombolites indicate that conditions actually favor microalgal growth. Thus, currently there is no clear explanation for the development of cyanobacteria mats and the eventual formation of pro-thrombolites.

In conclusion, besides providing clues for past microbial activity, cyanobacterial mats generate pro-thrombolithic structures, which in turn play important ecological or geological roles (i.e., hitherto overlooked landforming coastal processes). My observations support the proposed hypothesis that prothrombolithic development triggered the birth of the El Mogote sand bar by providing the necessary spit for the accumulation of sand and, through continuous growth for approximately six millennia, eventually transformed a primitive cove into the modern coastal lagoon known as Ensenada de La Paz.

In other parts of the lagoon margins, mainly at El Centenario, El Comitán, and El Conchalito Peninsula, where CICIMAR and the Centro de Estudios Tecnológicos del Mar (CETMAR) high school campuses stand, extensive pro-thrombolithic development is evidenced by exposed and buried supralittoral formations. These strongly indicate that these formations have generated large extensions of land (progradation) currently occupied by urban settlements of La Paz city. In El Comitán and El Centenario a different strategy in the search for lithified structures may be required due to the greater expansion of human settlements.

Further research is being planned to relate site conditions to differential thrombolite and pro-thrombolite formation in the lagoon.
The recently located formations found in $\mathrm{El}$ Mogote across the channel north of CICIMAR offer many opportunities for study. It is clear that much research needs to be done, and this will require preservation of these millenary formations. It is hoped that this report will draw attention to the value of the Ensenada de La Paz in furthering our understanding of biosedimentary structures and serve to support any preservation efforts to come.

\section{ACKNOWLEDGMENTS}

U. Argumedo and O. U. Hernández-Almeida helped during the field trips and in sample and image processing. J. Murillo de Nava of CICIMAR gave advice on field and laboratory geology, made the thin sections, and provided the preliminary petrographic description. I thank R. Shapiro, M. Johnson, and an anonymous reviewer for their precise observations.

\section{Literature Cited}

Alvarez-Arellano, A., H. Rojas-Soriano, and J. J. Prieto-Mendoza. 1997. Geología de la Bahía de La Paz y áreas adyacentes. Pages 13-29 in J. Urbán-Ramírez and M. Ramírez-Rodríguez, eds. La Bahía de La Paz: Investigación y conservación. Universidad Autónoma de Baja California SurCentro Interdisciplinario de Ciencias Marinas (IPN)-Scripps Institution of Oceanography.

Canet, C., R. M. Prol-Ledesma, I. TorresAlvarado, H. A. Gilg, R. E. Villanueva, and R. Lozano-Santa Cruz. 2005. Silicacarbonate stromatolites related to coastal hydrothermal venting in Bahía Concepción, Baja California Sur, México. Sediment. Geol. 174:97-113.

Cervantes-Duarte, R., F. Aguirre-Bahena, A. Reyes-Salinas, and J. E. Valdéz-Olguín. 2001. Caracterización hidrológica de una laguna costera de Baja California Sur, México. Oceánides 16:93-107.

Charpy, L., and A. W. D. Larkum, eds. 1999. Marine cyanobacteria. Bull. Inst. Océan- 
ogr. Mus. Océanogr. (Monaco). Num. spéc. 19.

Cruz-Orozco, R., P. Rojo-García, L. Godínez-Orta, and E. Nava-Sánchez. 1989. Topografía, hidrología y sedimentos de las márgenes de la Laguna de La Paz, B.C.S. Rev. Invest. Cient. Univ. Autón. Baja Calif. Sur 1:3-16.

Europa Technologies. 2007. http://earth .google.com.

Horodysky, R. J. 1977. Lyngbya mats at Laguna Mormona, Baja California, México: Comparison with Proterozoic stromatolites. J. Sediment. Petrol. 47:1305-1320.

Horodysky, R. J., and S. J. von der Haar. 1975. Recent calcareous stromatolites from Laguna Mormona (Baja California) México. J. Sediment. Petrol. 45:894-906.

Jiménez-Illescas, A. R., M. Obeso-Nieblas, and D. Salas-de León. 1997. Oceanografía física de La Bahía de La Paz. Pages 31-42 in J. Urbán-Ramírez and M. RamírezRodríguez, eds. La Bahía de La Paz: Investigación y conservación. Universidad Autónoma de Baja California Sur-Centro Interdisciplinario de Ciencias Marinas (IPN)-Scripps Institution of Oceanography.

Johnson, M. E., and J. Ledesma-Vázquez, eds. 1997. Pliocene carbonates and related facies flanking the Gulf of California, Baja California, México. Geol. Soc. Am. Spec. Pap. 318.

Krumbein, W. E. 1979. Photolithotrophic and chemoorganotrophic activity of bacteria and algae as related to beachrock formation and degradation (Gulf of Aqaba, Sinai). Geomicrobiol. J. 1:139-203.

López-Cortés, A. 1999. Marine cyanobacteria from Bahía Concepción, B.C.S., México. Pages 87-93 in L. Charpy and A. W. D. Larkum, eds. Marine cyanobacteria. Bull. Inst. Océanogr. Mus. Océanogr. (Monaco). Num. spéc. 19.

Margulis, L., E. S. Barghoorn, D. Ashendorf, S. Banerjee, D. Chase, S. Francis, S. Giovannoni, and J. F. Stoltz. 1980. The microbial community at Laguna Figueroa, Baja
California, México: Does it have Precambrian analogues? Precambrian Res. 11:93123.

Miranda-Aviléz, R., H. Beraldi-Campesi, M. J. Puy-Alquiza, and A. L. Carreño. 2005. Estromatolitos, tufas y travertinos de la sección El Morro: Depósitos relacionados con la primera incursión marina en la Cuenca de Santa Rosalía, Baja California Sur. Rev. Mex. Cienc. Geol. 22:148158.

Nava-Sánchez, E. H., and R. Cruz-Orozco. 1989. Origen y evolución geomorfológica de la Laguna de La Paz, Baja California Sur, México. Invest. Mar. Cent. Interdiscip. Cienc. Mar. 4:49-58.

Riding, R. 2000. Microbial carbonates: The geological record of calcified bacterialalgal mats and biofilms. Sedimentology 47 (suppl.): 179-214.

Salinas, Z. C., A. C. Leyva, D. B. Lluch, and E. R. Díaz. 1990. Distribución geográfica y variabilidad climática de los regimenes pluviométricos en Baja California Sur, México. Atmósfera 3:217-237.

Shapiro, R. 2000. A comment on the systematic confusion of thrombolites. Palaios 15 (2): 166-169.

Siqueiros-Beltrones, D. A. 1988. Diatomeas bentónicas de la Laguna Figueroa, Baja California. Cienc. Mar. 14:85-112. 1990. Association structure of benthic diatoms in a hypersaline environment. Cienc. Mar. 16:101-127.

- 2006. Diatomeas bentónicas asociadas a trombolitos recientes registrados por primera vez en México. Oceánides 21 ( 1 , 2): $113-143$.

Stal, L. J. 2000. Cyanobacterial mats and stromatolites. Pages 61-120 in B. A. Whitton and M. Potts, eds. The ecology of cyanobacteria: Their diversity in time and space. Kluwer Academic Publishers. Dordrecht, Netherlands.

Whitton, B. A., and M. Potts, eds. 2000. The ecology of cyanobacteria: Their diversity in time and space. Kluwer Academic Publishers. Dordrecht, Netherlands. 
